
\title{
25 Research Square \\ Effects of copper ions and copper nanomaterials on the output of amino acids from marine algae
}

\section{Wenqiu Huang}

Ocean University of China - Laoshan Campus: Ocean University of China

\section{Yuping Zhou}

Zhejiang University

\section{Ting Zhao}

Ocean University of China - Laoshan Campus: Ocean University of China

\section{Liju Tan}

Ocean University of China - Laoshan Campus: Ocean University of China

Jiangtao Wang ( $\nabla_{\text {jtwang@ouc.edu.cn ) }}$

College of Chemistry and Chemical Engineering

\section{Research Article}

Keywords: Nano-copper, Nano-copper oxide, Copper ion, Nanomaterial, Algae-derived amino acids, Skeletonema costatum, Nitzschia Closterium, Marine algae

Posted Date: March 29th, 2021

DOl: https://doi.org/10.21203/rs.3.rs-324563/v1

License: (c) (i) This work is licensed under a Creative Commons Attribution 4.0 International License. Read Full License 


\section{Abstract}

In this study, the effects of different copper's forms, metal salt $\left(\mathrm{Cu}^{2+}\right)$, nano-metal (nano-Cu) and nanometal oxide (nano-CuO), were tested on two marine algae named Skeletonema costatum and Nitzschia closterium. During a 96-hour exposure to nanoparticles (NPs) and salt, cell number, $\mathrm{Cu}^{2+}$ concentration in the culture medium, morphology and intracellular amino acids was measured to assess the toxicity of those copper materials and the toxicity mechanism of NPs. It was found that the toxicity of $\mathrm{Cu}^{2+}$, nano$\mathrm{Cu}$ and nano-CuO on marine phytoplankton decreased in order. The $\mathrm{EC}_{50}$ values of $\mathrm{Cu}^{2+}$ and nano-Cu for S. costatum and $N$. closterium ranged from 0.356 to $0.991 \mathrm{mg} / \mathrm{L}$ and 0.663 to $2.455 \mathrm{mg} / \mathrm{L}$, respectively. Nano-Cu inhibited the growth of marine phytoplankton mainly by releasing $\mathrm{Cu}^{2+}$, however, nano-CuO mainly produced toxic effects on microalgae through the effect of NPs. The secretion of extracellular polymeric substances by microalgae could be another possible reason for nano-Cu and nano-CuO to impose implications for microalgae. S. costatum was more sensitive to copper than N. closterium. $\mathrm{Cu}^{2+}$, nano- $\mathrm{Cu}$ and nano-CuO all reduced the total output of algae-derived amino acids by affecting the growth of phytoplankton and per-cell amino acids. This manuscript is of important implications to fill the data gaps for nano-Cu and nano-CuO risk assessment on marine algae.

\section{Introduction}

Nanoparticles (NPs) refer to particles with a nanometer-scale structural characteristic, generally ranging from $1 \sim 100 \mathrm{~nm}$ in least two dimensions (Shi 2007). Nanomaterials have been widely used in aerospace, electronics, chemical, metallurgy, military, nuclear, medical and biological engineering industry since the 1960s because of their outstanding properties (Zhai et al. 1999). Copper is an essential metal element for the growth of marine microalgae (Marangoni et al. 2017). An excessive amount of copper leads to significant adverse effects on algae, such as pool growth, inhibition of photosynthesis, and even death of cells in severe cases (Wang et al. 2018; Fawaz et al. 2018; Guo et al. 2019).

Nano-Cu and nano-CuO are wildly used for catalysis, drug additives, superconducting materials, etc., and tend to accumulate in the ocean during laboratory research, industrial production, transportation, consumption and disposal (Cui et al. 2013). Thus, it is necessary to study their ecotoxicity to nature environment. Marine microalgae are regarded as the significant primary producer in the ocean and the important source of marine amino acids (Li et al. 2009; Zhang et al. 2015), which are the most widely used test organism (Bondarenko 2016; Wang et al. 2019; Nguyen et al. 2020). Previous studies have reported nano-Cu and nano-CuO toxicity on freshwater algae (Müller et al. 2016; Zhao et al. 2016).

This study aimed to investigate the toxic effects and mechanism of different copper NPs on marine algae Nitzschia closterium, a commonly used marine bait in aquaculture (Sun et al. 2016), and Skeletonema costatum, a red tide species commonly found near the offshore area of China (Li et al. 2017). $\mathrm{Cu}^{2+}$ concentrations in the culture media were analyzed to assess the impact of NPs on microalgae. The number of cells and the cell morphology of algae observed by scanning electron microscope (SEM) were 
used to assess the toxicity mechanism and the interactions between NPs and microalgae. The production of algae-derived amino acids was determined to explore the effects of NPs on the ecosystem.

\section{Materials And Methods 2.1. Chemicals}

$\mathrm{CuSO}_{4} \cdot 5 \mathrm{H}_{2} \mathrm{O}$ (purity $>99.9 \%$ ) was purchased from Sinopharm Chemical Reagent Co., Ltd, China. Nanocopper powder (nano-Cu, purity > 99.9\%, 10-30 nm) and nano-copper oxide powder (nano-CuO, purity > 99.5\%, $40 \mathrm{~nm}$ ) were purchased from Shanghai Aladdin Co., Ltd., China. NPs suspensions and $\mathrm{CuSO}_{4} \cdot 5 \mathrm{H}_{2} \mathrm{O}$ solutions were prepared according to the procedure used by Zhang (2018). The SEM (Fig. S1) of nano-Cu, similar to nano-CuO, were shown in the previous study at our laboratory (Zhang et al. 2018). Hydrodynamic diameter (HDD) of nano-Cu and nano-CuO was measured by dynamic light scattering using a Malvern Zetasizer (Nano ZS, Malvern Panalytical Ltd, UK) every 24 hours up to 96 hours at the concentration of $10 \mathrm{mg} / \mathrm{L}$ to assess the aggregation of nano-Cu and nano-CuO in seawater (Fig. S2). The NPs tended to gather in the seawater, and were of stability in the experiment period with an average size of $194 \mathrm{~nm}$ for nano-Cu and $525 \mathrm{~nm}$ for nano-CuO. Zeta potential of nano-Cu and nano-CuO was also measured at the concentration of $10 \mathrm{mg} / \mathrm{L}$ at $24 \mathrm{~h}$ using Malvern Zetasizer. Zeta potential of nano-Cu and nano-CuO was $-13 \mathrm{mV}$ and $-19 \mathrm{mV}$, respectively.

\subsection{Algae cultures}

The test species, $N$. closterium and S. costatum, were obtained from the Algal Center of Key Laboratory of Marine Chemistry Theory and Technology, Ocean University of China.

Algae were cultivated in the incubator under fluorescent lights (4000 Ix) with a $12 \mathrm{~h}$ light-dark cycle at 20 $\pm 1^{\circ} \mathrm{C}$ in $\mathrm{f} / 2$ medium (Guillard and Ryther 1962 ) based on sterile filtered $(0.45 \mu \mathrm{m})$ seawater collected from the coastal sea near Qingdao, China. Containers were shaken three times every day to avoid the sedimentation of microalgae. The toxicity test was performed as the exponential growth phase approached.

\subsection{Test methods}

\subsubsection{Inhibition test of $\mathrm{Cu}^{2+}$, nano-Cu and nano-CuO on microalgae}

The inhibition test was performed in $96 \mathrm{~h}$ with the Guideline 201 of OECD (OECD Test No. 201 2011) adopted. $N$. closterium and $S$. costatum in the exponential growth phase were added into $f / 2$ medium in several $500 \mathrm{~mL}$ Erlenmeyer flasks. $\mathrm{Cu}^{2+}$ and well-dispersed nano-Cu and nano-CuO were then added into the flasks, respectively. Flasks were shaken three times every day to avoid the sedimentation of microalgae and allow gas exchange with outside air, and placed randomly to remove the influences of light or temperature. 
According to previous studies (Aruoja et al. 2009; Manusadžianas et al. 2012; Li et al. 2015; Zhang et al. 2018) and our pre-test, the concentrations of copper materials were set as follow. In the N. closterium treatment, copper was added at concentrations of $0.1,0.3,0.5,0.7$ and $1.0 \mathrm{mg} / \mathrm{L}$ for $\mathrm{Cu}^{2+}, 0.5,1.0,1.5,2.5$ and $5.0 \mathrm{mg} / \mathrm{L}$ for nano-Cu, and $5,10,30,50$ and $70 \mathrm{mg} / \mathrm{L}$ for nano-CuO. In the $S$. costatum treatment, $\mathrm{Cu}^{2+}$ was of $0.05,0.15,0.20,0.50$ and $1.00 \mathrm{mg} / \mathrm{L}$, nano-Cu of $0.1,0.5,1.0,2.0$ and $5.0 \mathrm{mg} / \mathrm{L}$ and nanoCuO of 1, 5, 10, 20 and $50 \mathrm{mg} / \mathrm{L}$, respectively. The treatment without any copper material was set as control $(0 \mathrm{mg} / \mathrm{L})$. Each of the treatments was run in triplicates. The cultures were sampled every $24 \mathrm{~h}$ for counting cell numbers using an inverted biological microscope with a hemocytometry. Samples after $48 \mathrm{~h}$ exposure were collected to access growth inhibition ratio (IR) (calculated according to the following Eq. (1)) and concentration for $50 \%$ of maximal effect $\left(E_{50}\right)$.

$\mathrm{IR} \%=(1-\mathrm{T} / \mathrm{C}) \times 100 \%(1)$

which $T$ is the density of microalgae cells in the treatment group, and $C$ is the density of microalgae cells in the control group (Šepič et al. 2003).

\subsubsection{Measurement of $\mathrm{Cu}^{2+}$ concentration}

The concentrations of $\mathrm{Cu}^{2+}$ in the cultures were measured using Inductively Coupled Plasma Optical Emission Spectrometer (ICP-OES, Thermo Fisher Scientific, USA) every 24 hours up to 96 hours at the concentration of $5 \mathrm{mg} / \mathrm{L}$ for nano-Cu and $50 \mathrm{mg} / \mathrm{L}$ for nano-CuO to assess the kinetics of ion release from the particles (Fan et al. 2012; Kim et al. 2013).

\subsubsection{Scanning electron microscope for algae}

S. costatum exposed for $96 \mathrm{~h}$ were collected and centrifuged at $1509 \times \mathrm{g}$ for 10 mins for cell morphology with the SEM. SEM measurements were performed on a Hitachi S-4800 SEM with luminescence (Japan). The sediment was collected and kept at $4^{\circ} \mathrm{C}$ for $12 \mathrm{~h}$ with glutaraldehyde $(2.5 \%)$ added, then washed three times with $0.1 \mathrm{~mol} / \mathrm{L}$ phosphate buffer solution (PBS, $\mathrm{pH}=7.4$ ) and were gradient dehydrated with ethanol-water solutions of different concentrations (30\%, 50\%, 70\%, $90 \%$ and $100 \%)$ in sequence. Each dehydration step lasted $20 \mathrm{~min}$. The dehydrated samples were kept in tert-butanol at $4^{\circ} \mathrm{C}$ and freeze-dried, then were coated on the conducting resin and observed.

\subsubsection{Analysis of intracellular amino acids}

The type and amount of intracellular amino acids (IAA) measurements were performed on a Hitachi L2000 high performance liquid chromatography (HPLC, Japan). Fourteen types of amino acids measured were aspartic acid (Asp), glutamic acid (Glu), serine (Ser), histidine (His), glycine (Gly), threonine (Thr), arginine (Arg), alanine (Ala), tyrosine (Tyr), valine (Val), methionine (Met), phenylalanine (Phe), isoleucine (Ile) and leucine (Leu) respectively (Zhang et al. 2015).

The cultures were centrifuged $(1509 \times \mathrm{g}, 10 \mathrm{~min})$ after $48 \mathrm{~h}$ exposure to collect algal cells. Then algal cells were washed with Miller-Q water three times to ensure no extracellular organic matter was left. The algal cells were disrupted using cell disruptor to ensure that intracellular organic matter (IOM) was released. 
The samples were then centrifuged $(4193 \times \mathrm{g}, 15 \mathrm{~min})$ to obtain supernatant containing IOM for total IAA analysis (Zhang, P.Y. et al. 2016). The supernatant, ascorbic acid and $\mathrm{HCl}(6 \mathrm{~mol} / \mathrm{L})$ were added into the ampoule bottles, which were then flame sealed under $\mathrm{N}_{2}$ atmosphere. The samples were hydrolyzed at $110^{\circ} \mathrm{C}$ for $22 \mathrm{~h}$ then cooled. Milli-Q water was added to dissolve the dried hydrolysate for derivatization before analysis. A modified pre-column o-Phthaldialdehyde derivatization method (Zhang, P.Y. et al. 2016; Lindroth and Mopper 1979) was used before determining the samples with HPLC. Gradient elution separation was performed on HPLC for amino acid determination. The mobile phases were (A) methanol: acetonitrile: Milli-Q water $=1: 1: 1(\mathrm{v} / \mathrm{v} / \mathrm{v})$ and $(\mathrm{B})$ acetic acid buffer $(0.05 \mathrm{M}, \mathrm{pH}=7.2)$ : tetrahydrofuran = 100:1 (v/v).

\subsection{Statistical analysis}

Statistical analysis was performed using SPSS 21 . The normality of was checked by the Shapiro-Wilk's normality test ( $p>0.05$ in all treatments), and then homogeneity of variance for data was assessed with the Levene test ( $p>0.05$ in all treatments). One-way analysis of variance (ANOVA) with a least significant difference (LSD) post hoc-test $(p<0.05)$ was performed to test differences in IR and per-cell IAA content among different concentration groups in each copper material treatment. In the figures, values are presented as mean \pm standard deviation (SD, shown as error bars), and the results of LSD's test were performed as different small letters which means statistically significant differences $(p<0.05)$ exist between groups marked with different small letters.

Toxicity regression equations fitting and $\mathrm{EC}_{50}$ calculation were performed under a confidence interval of 95\% with Probit analysis adapted (Wu et al. 2014; Feng et al. 2019). Inhibition ratio, concentration and sum were set as variables, and $\mathrm{EC}_{50}$ of different copper materials were calculated though Probit process with covariate transformed into log base 10 . Probit model in the parameter estimate was the toxicity regression equations for different copper materials. Chi-square test was used to check the fitting degree

of toxic regression equations. $\chi^{2}<\chi_{0.05(3)}{ }^{2}=7.815(\mathrm{df}=3)$ and $p>0.050$ mean toxicology regression equation was well-fitted ( $\chi$ means copper concentration transformed into log base 10 ). When $\chi^{2}>\chi_{0.05(3)}{ }^{2}$ $=7.815(\mathrm{df}=3)$ and $p<0.150$, heterogeneity factors were applied in the calculation of the confidence limits (details see Tab. S2).

\section{Results}

\subsection{Algae responded to $\mathrm{Cu}^{2+}$, nano-Cu and nano-CuO exposure}

The exposure to $\mathrm{Cu}^{2+}$, nano-Cu and nano-CuO had significant effects on algal growth. As shown in Fig. 1 (data in Tab. S1), the IR increased with the increasing concentrations and exposure time, which performed different levels according to the types of material. 
For $N$. closterium treatment (Fig. $1 \mathrm{~A}$ ), the $I R$ of $\mathrm{Cu}^{2+}$ exceeded $50 \%$ at the concentration of $0.7 \mathrm{mg} / \mathrm{L}$, and reached $69.8 \%$ at the highest concentration of $1.0 \mathrm{mg} / \mathrm{L}$. As for nano-Cu exposed, $I R$ reached $59.6 \%$ at the concentration of $2.5 \mathrm{mg} / \mathrm{L}$ and $64.5 \%$ at the highest concentration of $5.0 \mathrm{mg} / \mathrm{L}$. Even at the maximum concentration of $70 \mathrm{mg} / \mathrm{L}$ for nano-CuO, the $I R$ was only $34.9 \%$.

The IR of S. costatum increased with the increasing copper concentrations (Fig. 1B). IR exceeded $50 \%$ at the concentration of $0.5 \mathrm{mg} / \mathrm{L}$ for $\mathrm{Cu}^{2+}$, and reached $87.7 \%$ at the highest concentration of $1.0 \mathrm{mg} / \mathrm{L}$. IR reached a high level of $78.2 \%$ under $2.0 \mathrm{mg} / \mathrm{L}$ of nano-Cu. $I R$ was only $40.5 \%$ under the maximum nanoCuO concentration of $50 \mathrm{mg} / \mathrm{L}$. The significant differences $(p<0.05)$ in all treatments indicated that $\mathrm{Cu}^{2+}$, nano-Cu and nano-CuO were toxic to N. closterium and S. costatum.

In order to compare the sensitivity of $S$. costatum and $N$. closterium to different forms of copper, $48 \mathrm{~h}$ toxicity regression equations and $\mathrm{EC}_{50}$ were calculated and shown in Table 1 (more details in Tab. S2). The $\mathrm{EC}_{50}$ of $\mathrm{Cu}^{2+}$ for $S$. costatum was $0.356 \mathrm{mg} / \mathrm{L}$, less than $0.663 \mathrm{mg} / \mathrm{L}$ for $N$. closterium. Similarly, the $\mathrm{EC}_{50}$ of nano-Cu for $S$. costatum was $0.991 \mathrm{mg} / \mathrm{L}$, less than $2.455 \mathrm{mg} / \mathrm{L}$ for $N$. closterium, indicating that $S$. costatum was more sensitive than $N$. closterium with a tendency for $\mathrm{Cu}^{2+}$ to be of more inhibitory than nano- $\mathrm{Cu}$. $\mathrm{EC}_{50}$ of nano-CuO performed large errors because the inhibition ratios were less than $50 \%$ in all nano-CuO treatments, thus not shown.

Table 1

$\mathrm{EC}_{50}$ of nano-Cu and nano-CuO on Skeletonema costatum and Nitzschia closterium

\begin{tabular}{|llll|}
\hline N. & Microalgae & Copper Material & $\mathrm{EC}_{50}(\mathrm{mg} / \mathrm{L})$ \\
& N. closterium & $\mathrm{Cu}^{2+}$ & 0.663 \\
\cline { 3 - 4 } & Nano-Cu & 2.455 \\
\cline { 3 - 4 } & S. costatum & $\mathrm{Cu}^{2+}$ & 0.356 \\
\cline { 3 - 4 } & & Nano-Cu & 0.991 \\
\hline
\end{tabular}

\section{2. $\mathrm{Cu}^{2+}$ concentration in the cultures}

$\mathrm{Cu}^{2+}$ dissolution in culture medium at the concentration of $5 \mathrm{mg} / \mathrm{L}$ for nano- $\mathrm{Cu}$ and $50 \mathrm{mg} / \mathrm{L} \mathrm{for} \mathrm{nano-}$ $\mathrm{CuO}$ showed that ion dissolution rates of nano-Cu and nano-CuO seem to decline with time (Fig. S3). $\mathrm{Cu}^{2+}$ concentrations in the cultures of $S$. costatum at $96 \mathrm{~h}$ were presented in Fig. 2, showing a tendency that higher concentrations of $\mathrm{Cu}^{2+}$ were measured in seawater as more copper materials added. The result was also corroborated with $\mathrm{Li}$ (2015). When the concentration of nano-Cu was $5 \mathrm{mg} / \mathrm{L}$, the concentration of $\mathrm{Cu}^{2+}$ in the culture medium was $0.68 \mathrm{mg} / \mathrm{L}$, which was about the same level with 1 $\mathrm{mg} / \mathrm{L}$ of $\mathrm{Cu}^{2+}$ added, and they both showed high inhibition ratios on $\mathrm{N}$. closterium and $\mathrm{S}$. costatum. The 
concentration of $\mathrm{Cu}^{2+}$ was only $0.24 \mathrm{mg} / \mathrm{L}$ in seawater with $50 \mathrm{mg} / \mathrm{L}$ of nano-CuO added, which also indicated that nano-Cu was more likely to release $\mathrm{Cu}^{2+}$ than nano-CuO.

\subsection{Cell morphology}

Under nano-Cu stress condition, the changed morphology of $S$. costatum and broken siliceous thorns were observed in Fig. 3. Extracellular polymeric substances (EPS) released by algae were also observed (arrow a).

\subsection{Effect of $\mathrm{Cu}^{2+}$, nano-Cu and nano-CuO on algae-derived amino acids}

IAAs at $48 \mathrm{~h}$ significant changed as shown in Fig. 4. Amino acid decreased gradually with the increasing exposure concentrations, which suggested that copper materials inhibited biosynthesis of total IAA. Large errors were observed in treatments with low cell density (for example, treatments under $1.0 \mathrm{mg} / \mathrm{L}$ of $\mathrm{Cu}^{2+}$, 2.0 and $5.0 \mathrm{mg} / \mathrm{L}$ of nano- $\mathrm{Cu}$ ), thus not shown in the figure.

IAAs of $N$. closterium decreased from $3994.9 \mathrm{nmol} / \mathrm{L}$ to $3391.4 \mathrm{nmol} / \mathrm{L}$ and $2686.0 \mathrm{nmol} / \mathrm{L}(84.9 \%$ and $67.2 \%$ of the control) as exposure concentration of $\mathrm{Cu}^{2+}$ were 0.1 and $1.0 \mathrm{mg} / \mathrm{L}$, respectively. The concentrations of IAA exposed to $5.0 \mathrm{mg} / \mathrm{L}$ of nano-Cu and $70 \mathrm{mg} / \mathrm{L}$ of nano-CuO were $1948.1 \mathrm{nmol} / \mathrm{L}$ ( $48.8 \%$ of the control) and $3038.3 \mathrm{nmol} / \mathrm{L}$ ( $76.1 \%$ of the control), respectively. Under nano-CuO exposure, no significant decline of IAA was detected in compared to $\mathrm{Cu}^{2+}$ and nano-Cu. The main composition of IAA found in algae were Gly, Glu, Ser and Ala with total content more than $50 \%$ of total IAA (Fig. 4).

For $S$. costatum, IAA also gradually decreased with the increasing concentrations of $\mathrm{Cu}^{2+}$, nano-Cu and nano-CuO. The concentration of IAA decreased from 1284.77 to $534.02 \mathrm{nmol} / \mathrm{L}$ ( $41.6 \%$ of the control) as exposed to $1.0 \mathrm{mg} / \mathrm{L}$ of $\mathrm{Cu}^{2+}$ for $48 \mathrm{~h}$. IAA reduced by approximately $53.5 \%$ for $1.0 \mathrm{mg} / \mathrm{L}$ of nano-Cu and $52.9 \%$ for $50 \mathrm{mg} / \mathrm{L}$ of nano-CuO, respectively. Gly, Glu, Ser and Ala accounted for more than $40 \%$ in total IAA of $S$. costatum. Like $N$. closterium, the proportion remained fairly stable.

To further investigate the effect of copper on IAA of microalgae, the changes of per-cell amino acids were analyzed and shown in Fig. 5 (data see Tab. S3). The IAA of single cells for $N$. closterium fluctuated between 9.83 and $20.14 \mathrm{nmol} / \mathrm{L}$, and significant differences were observed among $\mathrm{Cu}^{2+}$ and nano-Cu treatments $(p<0.05)$ with a increasing trend. Meanwhile, it was slightly different from nano-CuO treatment with a modest rise as concentrations increased. However, no significant differences were observed in all S. costatum treatments (Fig. 5B, p>0.05).

\section{Discussion}

\subsection{Effect of $\mathrm{Cu}^{2+}$, nano-Cu and nano-CuO on the growth of microalgae}


In this research, it was found that the growth of phytoplankton was significantly inhibited when exposed to metal salt $\left(\mathrm{Cu}^{2+}\right)$, nano-metal (nano-Cu) and nano-metal oxide (nano-CuO) with a rising trend of inhibition ratios as exposure concentrations increased. Different microalgae responded differently to copper materials, and S. costatum was more sensitive than N. closterium. Copper is one of necessary trace elements in growth of phytoplankton (Leusch et al. 1995). Nevertheless, it has been proved to inhibit the photosynthesis of phytoplankton, reduce the amount of chlorophyll, and lead to changes in cell morphology and enzyme activity at high concentrations (Stampoulis et al. 2009; Lu et al. 2010; El-Kassas et al. 2017; Guo et al. 2019).

$\mathrm{Li}$ (2015) reported that nano-Cu (10-30nm) was toxic to $S$. costatum with a $96 \mathrm{~h} \mathrm{EC} \mathrm{E}_{50}$ of $0.10 \mathrm{mg} / \mathrm{L}$, which was less than our results. A possible explanation for this might be the different exposure time chosen. According to Joonas (2019), $72 \mathrm{~h} \mathrm{EC}_{50}$ of nano-CuO $(22-25 \mathrm{~nm})$ to the diatom Fistulifera pelliculosa was $0.65 \mathrm{mg} / \mathrm{L}$, which educed that $F$. pelliculosa was a more sensitive marine algae than the two diatoms used in our research. Details of comparison were listed in Table 2. We also found the toxicity of $\mathrm{Cu}^{2+}$, nano-Cu and nano-CuO decrease in order. This finding supports evidence for previous observations that the ionic form of metals is more toxic than NPs (Batley et al. 2012; Bielmyer et al. 2006; Turan et al. 2019).

Table 2

List of $\mathrm{EC}_{50}$ about nano-Cu or nano-CuO on marine algae.

\begin{tabular}{|c|c|c|c|c|c|c|}
\hline Species & $\begin{array}{l}\text { Test } \\
\text { material }\end{array}$ & $\begin{array}{l}\text { Exposure } \\
\text { time and } \\
\text { endpoint }\end{array}$ & $\begin{array}{l}\mathrm{EC}_{50} \text { on } \\
\text { compound } \\
\text { basis, } \\
\mathrm{mg} / \mathrm{L}\end{array}$ & $\begin{array}{l}\mathrm{EC}_{50} \text { on } \\
\text { metal } \\
\text { basis, } \\
\mathrm{mg} \mathrm{Cu} / \mathrm{L}\end{array}$ & $\begin{array}{l}\text { Primary size } \\
\text { (method used for } \\
\text { determination), } \\
\text { coating }\end{array}$ & Reference \\
\hline $\begin{array}{l}\text { Skeletonema } \\
\text { costatum }\end{array}$ & $\begin{array}{l}\text { Nano- } \\
\mathrm{Cu}\end{array}$ & $96 \mathrm{~h} \mathrm{EC}_{50}$ & 0.10 & 0.08 & $\begin{array}{l}10-30 \mathrm{~nm} \\
\text { (provider), } \\
\text { uncoated }\end{array}$ & $\begin{array}{l}\text { Li et al. } \\
2015\end{array}$ \\
\hline $\begin{array}{l}\text { Fistulifera } \\
\text { pelliculosa }\end{array}$ & $\begin{array}{l}\text { Nano- } \\
\mathrm{CuO}\end{array}$ & $72 \mathrm{~h} \mathrm{EC}_{50}$ & 0.65 & 0.52 & $\begin{array}{l}22-25 \mathrm{~nm} \\
\text { (provider), } \\
\text { uncoated }\end{array}$ & $\begin{array}{l}\text { Joonas et } \\
\text { al. } 2019\end{array}$ \\
\hline $\begin{array}{l}\text { Skeletonema } \\
\text { costatum }\end{array}$ & $\begin{array}{l}\text { Nano- } \\
\mathrm{Cu}\end{array}$ & $48 \mathrm{hC}_{50}$ & 0.99 & 0.79 & $\begin{array}{l}\text { 10-30nm (provider), } \\
\text { uncoated }\end{array}$ & $\begin{array}{l}\text { This } \\
\text { research }\end{array}$ \\
\hline $\begin{array}{l}\text { Nitzschia } \\
\text { closterium }\end{array}$ & $\begin{array}{l}\text { Nano- } \\
\mathrm{Cu}\end{array}$ & $48 \mathrm{hEC}_{50}$ & 2.46 & 1.96 & $\begin{array}{l}\text { 10-30nm (provider), } \\
\text { uncoated }\end{array}$ & $\begin{array}{l}\text { This } \\
\text { research }\end{array}$ \\
\hline
\end{tabular}

Toxicity mechanisms of NPs on algae include changing cell membrane structure or potentials, oxidizing protein, causing genetic mutation, interrupting energy transfer, inducing activated oxygen or releasing ions (Klaine et al. 2008). The results (Fig. 2) revealed that nano-Cu and nano-CuO could release $\mathrm{Cu}^{2+}$ into seawater. Both nano-Cu and comparable amount of $\mathrm{Cu}^{2+}$ showed considerable inhibition ratios on 
microalgae, which suggested that the toxicity of nano-Cu was mainly due to $\mathrm{Cu}^{2+}$ released into water, and this finding was also proved by $\mathrm{Li}$ (2015) and Bondarenko (2012). Some researchers believed that ion release resulted in the toxicity of NPs (Jo et al. 2012; Kim et al. 2011). Wong (2010) conducted experiments on two diatoms and found that zinc ions release was nano-ZnO's main toxicity mechanism. Yuan (2013) declared that silver NPs released $\mathrm{Ag}^{+}$into solution, which inhibited the growth of Chlorella vulgari. The results also suggest that nano-CuO hardly dissolved $\mathrm{Cu}^{2+}$ into seawater at low concentrations $(0-10 \mathrm{mg} / \mathrm{L})$ compared to nano- $\mathrm{Cu}$, indicating that the possible transformation pathways of nano-Cu and nano-CuO into $\mathrm{Cu}^{2+}$ could be different. Nano-Cu underwent electrochemical corrosion with dissolved oxygen or other oxidants in seawater. Copper acted as an anode in the oxidation reaction (Eq. (2)) and released $\mathrm{Cu}^{2+}$ into seawater (Wang et al. 1997; Huang et al. 2017).

$$
\mathrm{Cu} \rightarrow \mathrm{Cu}^{2+}+2 \mathrm{e}^{-}(2)
$$

The covalent bonds of $\mathrm{CuO}$ are quite stable and not easy to be broken, which could hardly produce $\mathrm{Cu}^{2+}$. A small amount of free $\mathrm{H}^{+}$in seawater could combine with nano-CuO to produce $\mathrm{Cu}^{2+}$ according to reaction Eq. (3). The amount of $\mathrm{Cu}^{2+}$ produced by nano-CuO was much less than that by nano-Cu.

$$
\mathrm{Cu}+2 \mathrm{H}^{+} \rightarrow \mathrm{Cu}^{2+}+\mathrm{H}_{2} \mathrm{O}(3)
$$

This outcome is inconsistent with that of Wu (2020), who found no significant difference in ion concentrations between nano- $\mathrm{Cu}$ and nano-CuO dissolved in the water. This could mainly result from that they have chosen nano-Cu with a $1.4 \mathrm{~nm}$ oxidized copper outer shell (diameter $<50 \mathrm{~nm}$ ) and nano-CuO (diameter $<50 \mathrm{~nm}$ ) as test materials the similar characteristics. The oxidized copper shell outside of the nano-Cu might participate in the ion release at first, leading to the similar dissolved ion concentration with nano-CuO.

The concentration of $1 \mathrm{mg} / \mathrm{L}$ nano-CuO still inhibited the growth of $S$. costatum (inhibition ratio of $5.7 \%$ ) with negligible dissolution of $\mathrm{Cu}^{2+}$, indicating the toxicity of nano-CuO could not be mainly expressed by the dissolved fraction (Ye et al. 2017; Xiang et al. 2011; Nguyen et al. 2020). Cui et al. (2013) also found nano-CuO was of higher toxicity than comparable amount of $\mathrm{Cu}^{2+}$ on goldfish algae, and they attributed this to the special surface effect and quantum size effect of nano-CuO.

Nano-Cu or nano-CuO aggregated together and formed large-sized NPs, directly contacting with microalgae. Effects of nanomaterial can be determined as mechanical damage and shading effect (Zhao et al. 2016; Toh et al. 2016; Wang et al. 2016; Zhao et al. 2017). Physical damage of cell membranes with CuO NP exposure were also observed by Zhao et al. (2016), who found this exposure caused much stronger damage than the released $\mathrm{Cu}^{2+}$ ions did. NPs also covered the surface of microalgae, causing the shading effect which, in addition, hindered the microalgae to exchange substance and energy with the 
surrounding environment, thus inhibiting the growth of microalgae (Tang et al. 2015; Zhang C. et al. 2016; Chen et al. 2017).

It was reported that many algae secreted EPS, especially in high cell density or under environmental stress due to light and nutrient restriction or excessive heavy metal, etc. (Staats et al. 2000; Passow 2002; Underwood et al. 2004). EPS could help microalgae adjust the interaction between NPs and cell membranes (Unrine et al. 2012; Zhao et al. 2019). It was hypothesized that EPS reduced the possibility of direct contact between NPs and cells through adsorbing NPs or adhering to the surface of cells which separated the NPs from outside (Zhou et al. 2016) and induces cell aggregation to reduce the specific surface area of algae. EPS could also adsorb part of $\mathrm{Cu}^{2+}$ to alleviate the adverse effects of released ions, and this need further research. However, the EPS was in small amount and in filamentous shape with minimal possibility of absorbing NPs and ions, but causing collisions between algae cells and EPS (Long et al. 2015). Thus, it was suggested that EPS hardly protect the algae under nano-CuO because the toxicity of nano-CuO was mainly caused by ion release, but EPS could partly alleviate the toxicity of nano$\mathrm{CuO}$ because its toxicity was mainly caused by nanomaterial effects.

In conclusion, there are three ways which exerted influence on algae cells by nano-Cu and nano-CuO as

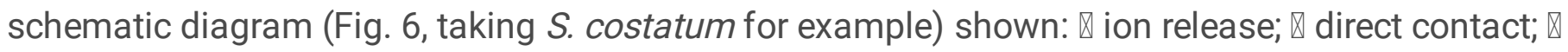
stimulating algae cells to secret EPS. Releasing ion was the main toxicity mechanisms for nano-Cu, while direct contact was for nano-CuO. The secretion of EPS could be the protective mechanism to some extent.

\subsection{Effect of $\mathrm{Cu}^{2+}$, nano-Cu and nano-CuO on algae-derived amino acids}

According to this research, Gly, Glu, Ser and Ala were the main types of amino acids both in N. closterium and $S$. costatum, and the content of which dropped as more severe inhibition on the growth of algae. In contrast, the percentage of these four kinds of amino acids in the total amino acid content remained stable as concentrations increased (shown as line in Fig. 4), indicating the proportion was not affected by copper.

The addition of $\mathrm{Cu}^{2+}$, nano-Cu and nano-CuO led to the decline of cell density and changes in per-cell IAA, which resulted in the significant decrease of total IAA. The difference in change of per-cell IAA may result from the characteristics of different algae. Microalgae could cope with copper by self-regulating, mainly performed as changes in types and content of proteins (Wong et al. 2010). Besides, it has been reported that organisms, especially monads, adapt to environmental stress by changing cell size or specific surface area (Xue et al. 2018). Toxic substances were possible to result in retard of chloroplast division and prevent the protoplast from dividing at low concentration (Li et al. 2019; Liu et al. 2016; Gu et al. 2017), thus leading to the increase in cell size by growing but not dividing (Chao and Chen 2001; Machado et al. 2014). In this situation, amino acid content in single cells increased, which corresponded to the $N$. closterium treated with $\mathrm{Cu}^{2+}$ and nano-Cu at high concentrations. As the concentration of toxic 
substances increased, algal cells' physiological function (such as photosynthesis and respiration) was further attenuated (Li et al. 2019; Liu et al. 2016; M'Rabet et al. 2018). And the cells could no longer cope with heavy metals by changing the cell volume. The cell volume was equivalent to the control group or even shrank, so there was no significant difference in the per-cell amino acid content, which corresponded to the treatment group of $S$. costatum which was poorly resistant to copper. It could be concluded that the prime cause of changes in per-cell amino acid content mainly lies in the influence on the growth cycle of microalgae cells and the inhibitory effect on algal reproduction and division, which in turn affects the cell volume and size, thus making the single cell amino acid content change.

\section{Conclusion}

The toxicity of $\mathrm{Cu}^{2+}$, nano-Cu and nano-CuO reduced in order, showing time and dose effects. Compared to the significant inhibition ratios by $\mathrm{Cu}^{2+}$ with $48 \mathrm{~h} \mathrm{EC}_{50}$ ranging from 0.356 to $0.991 \mathrm{mg} / \mathrm{L}$ and nano-Cu from 0.663 to $2.455 \mathrm{mg} / \mathrm{L}$, nano-CuO showed low inhibitory effects even at high concentrations, in which S. costatum was more sensitive than N. closterium. Inhibition of algae by nano-Cu and nano-CuO, substances with different dissolved mechanisms, was induced in different modes. Nano-Cu mainly inhibited the growth of marine phytoplankton by releasing $\mathrm{Cu}^{2+}$. But nano-CuO mainly inhibited the growth of microalgae through NP effects, i.e., mechanical damage and shading effect. Causing collisions between algae and EPS, the EPS could alleviate nano-CuO's toxicity, but made no effects to protect algae from nano-Cu poison. The inhibition of heavy metal on phytoplankton could alter the output of algaederived amino acids to the ocean by impacting on cell density and per-cell IAA which changed with the cell volume.

\section{Declarations}

\section{Acknowledgments}

This work was supported by the National Key Research and Development Program [grant number 2019YFC1407802, 2016YFC1402101]; the National Natural Science Foundation of China [grant number 41876078]; and the Natural Science Foundation of Shandong Province [grant number ZR2018MD016].

- Ethics approval and consent to participate

Not applicable

- Consent for publication

Not applicable

- Availability of data and materials 
All data generated or analysed during this study are included in this published article [and its supplementary information files].

- Competing interests

The authors declare that they have no competing interests.

- Funding

This work was supported by the National Key Research and Development Program [grant number 2019YFC1407802, 2016YFC1402101]; the National Natural Science Foundation of China [grant number 41876078]; and the Natural Science Foundation of Shandong Province [grant number ZR2018MD016].

- Authors' contributions

Wenqiu Huang: Term, Conceptualization, Methodology, Formal analysis, Investigation, Data Curation, Writing-Original Draft, Validation, Writing-Review \& Editing.

Yuping Zhou: Validation, Methodology.

Ting Zhao: Investigation.

Liju Tan: Resources, Funding acquisition.

Jiangtao Wang: Resources, Writing-Review \& Editing, Funding acquisition, Supervision.

All authors read and approved the final manuscript.

\section{Abbreviations}

EPS

HDD

IAA

IOM

$\operatorname{IR}$

$N$ closterium

NPs

S. costatum

SEM extracellular polymeric substances

hydrodynamic diameter

intracellular amino acids

intracellular organic matter

inhibition ratio

Nitzschia closterium

nanopaerticles

Skeletonema costatum

scanning electron microscope 


\section{References}

Aruoja V, Dubourguier HC, Kasemets K, Kahru A (2009) Toxicity of nanoparticles of $\mathrm{CuO}, \mathrm{ZnO}$ and $\mathrm{TiO}_{2}$ to microalgae Pseudokirchneriella subcapitata. Sci Total Environ 407(4):1461-1468.

https://doi.org/10.1016/j.scitotenv.2008.10.053

Batley GE, Kirby JK, McLaughlin MJ (2012) Fate and risks of nanomaterials in aquatic and terrestrial environments. Acc Chem Res 46:854-862. https://doi.org/ 10.1021/ar2003368

Bielmyer GK, Grosell M, Brix KV (2006) Toxicity of silver, zinc, copper, and nickel to the copepod Acartia tonsa exposed via a phytoplankton diet. Environ Sci Technol 40:2063-2068.

https://doi.org/10.1021/es051589a

Bondarenko O, Ivask A, Käkinen A, Kahru A (2012) Sub-toxic effects of CuO nanoparticles on bacteria: Kinetics, role of $\mathrm{Cu}$ ions and possible mechanisms of action. Environ Pollut 169:81-89. https://doi.org/10.1016/j.envpol.2012.05.009

Bondarenko OM, Heinlaan M, Sihtmäe M, Ivask A, Kurvet I, Joonas E, Jemec A, Mannerström M, Heinonen T, Rekulapelly R, Singh S, Zou J, Pyykkö I, Drobne D, Kahru A (2016) Multilaboratory evaluation of 15 bioassays for (eco)toxicity screening and hazard ranking of engineered nanomaterials: FP7 project NANOVALID. Nanotoxicology 10(9):1229-1242. https://doi.org/10.1080/17435390.2016.1196251

Chao R.M., Chen, C.Y., 2001. Discrepancies between different response parameters in batch and continuous algal toxicity tests. J. Hazard. Mater. 82(2):129-136. https://doi.org/10.1016/S03043894(00)00367-8

Chen XH, Zhang W, Tan LJ, Wang JT (2017) Research progress in toxicity of nanomaterials manufactured on microalgae. Mar Sci 41(6):134-143. https://doi.org/10.11759/hykx20161227001

Cui J, Yuan XY, Liu Q, Guo RR (2013) Toxic effects of low concentration copper oxide nanoparticles on Ceratophyllum demersum in the aquatic environment. J Agro-Environ Sci 5:910-915. http://www.cnki.com.cn/Article/CJFDTotal-NHBH201305007.htm

El-Kassas HY, Okbah MAEA (2017) Phytotoxic effects of seaweed mediated copper nanoparticles against the harmful alga: Lyngbya majuscule. J Genet Eng Biotechnol 15(1):41-48.

https://doi.org/10.1016/j.jgeb.2017.01.002.

Fan WH, Shi ZW, Yang XP, Cui MM, Wang XL, Zhang DF, Liu H, Guo L (2012) Bioaccumulation and biomarker responses of cubic and octahedral $\mathrm{Cu}_{2} \mathrm{O}$ micro/nanocrystals in Daphnia magna. Water Res 45(18):5981-5988. https://doi.org/10.1016/j.watres.2012.08.019

Fawaz EG, Salam DA, Kamareddine L (2018) Evaluation of copper toxicity using site specific algae and water chemistry: Field validation of laboratory bioassays. Ecotoxicol Environ Saf 155:59-65. 
Feng XF, Wang ZW, Xiong JH, Liu GQ, Chen YH, Ma JP (2019) Antibacterial activity of 4 kinds of asteraceae extracts against juglans regia pathogenic fungi. J Southwest For Coll 39(4):103-109. https://doi.org/10.11929/j.swfu.201810002

Gu SR, Zheng H, Xu QQ, Sun CZ, Shi M, Wang ZY, Li FM (2017) Comparative toxicity of the plasticizer dibutyl phthalate to two freshwater algae. Aquat Toxicol 191:122-130.

https://doi.org/10.1016/10.1016/j.aquatox.2017.08.007

Guillard RR, Ryther JH (1962) Studies of marine planktonic diatoms: I. Cyclotella nana hustedt, and Detonula confervacea (CLEVE) gran. Can J Microbiol 8(2):229-239. https://doi.org/10.1139/m62-029

Guo HS, Ling N, Liu XR, Cao XX, Lang L, Qi Z, Cui D, Liu B, Song DX, Ji CF, Lin YM (2019) Physiological response of Dunaliella salina to heavy metal copper stress (in Chinese). J Harbin Univ Commer 35(1):1-5. https://doi.org/10.3969/j.issn.1672-0946.2019.01.001

Huang GQ, Yang HY, Liu W (2017) Influences of copper ions dissolved out of copper samples on corrosion of aluminum alloys in seawater. Equip Environ Eng 14(2):1-5.

http://www.cqvip.com/QK/89536X/201702/671493141.html

Jo HJ, Choi JW, Lee SH, Hong SW (2012) Acute toxicity of Ag and CuO nanoparticle suspensions against Daphnia magna: the importance of their dissolved fraction varying with preparation methods. $J$ Hazard Mater 227-228:301-308. https://doi.org/10.1016/j.jhazmat.2012.05.066

Joonas E, Aruoja V, Olli K, Kahru A (2019) Environmental safety data on $\mathrm{CuO}$ and $\mathrm{TiO}_{2}$ nanoparticles for multiple algal species in natural water: Filling the data gaps for risk assessment. Sci Total Environ 647:973-980. https://doi.org/10.1016/j.scitotenv.2018.07.446

Kim KT, Truong L, Wehmas L, Tanguay RL (2013) Silver nanoparticle toxicity in the embryonic zebrafish is governed by particle dispersion and ionic environment. Nanotechnology 24:115101.

https://doi.org/10.1088/0957-4484/24/11/115101

Kim J, Kim S, Lee S (2011) Differentiation of the toxicities of silver nanoparticles and silver ions to the Japanese medaka (Oryzias latipes) and the cladoceran Daphnia magna. Nanotoxicology 5:208-214. https://doi.org/10.3109/17435390.2010.508137

Klaine SJ, Alvarez PJJ, Batley GE, Fernandes TF, Handy RD, Lyon D, McLaughlin MJ, Lead JR (2008) Nanomaterials in the environment: Behavior, fate, bioavailability and effects. Environ Toxicol Chem 27(9):1825-1851. https://doi.org/10.1897/08-090.1

Leusch A, Holan ZR, Volesky B (1995) Biosorption of heavy metals (Cd, Cu, Ni, Pb, Zn) by chemicallyreinforced biomass of marine algae. J Chem Technol Biotechnol 62(3):279-288. 
https://doi.org/10.1002/jctb.280620311

Li FF, Pan R, Zhang C, Wang JT (2015) Inhibition effects of copper nanoparticles on the growth of Skeletonema costatum (in Chinese). China Environ Sci 9:2874-2880. https://doi.org/10.3969/j.issn.10006923.2015.09.048

Li Y, Zhu L, Liu S (2009) Individual and joint stress of lead and mercury on growth, glutathione and glutathione-related enzymes of Scenedesmus quadricauda (in Chinese). China J Environ Sci 1:248-253. https://doi.org/10.3321/j.issn:0250-3301.2009.01.042

Li ZC, Yi XL, Zhou H, Chi TT, Li WT, Yang KM (2019) Combined effect of polystyrene microplastics and dibutyl phthalate on the microalgae Chlorella pyrenoidosa. Environ Pollut 257:113604. https://doi.org/10.1016/j.envpol.2019.113604

Li ZL, Zhou YL, Wang XJ, Shi XY, Zhang CS (2017) Effect of urea on the growth of Skeletonema costatum and Karenia mikimotoi. Acta Ecol Sin 37(9):3193-3200. https://doi.org/10.5846/stxb201601130085

Lindroth P, Mopper K (1979) High performance liquid chromatographic determination of subpicomole amounts of amino acids by precolumn fluorescence derivatization with o-Phthaldialdehyde. Anal Chem 51(11):1667-1674. https://doi.org/10.1016/10.1021/ac50047a019

Liu N, Wen FL, Li FM, Zhang X, Liang Z, Zheng H (2016) Inhibitory mechanism of phthalate esters on Karenia brevis. Chemosphere 155:498-508. https://doi.org/10.1016/j.chemosphere.2016.04.082

Long M, Moriceau B, Gallinari M, Lambert C, Huvet A, Raffray J, Soudant P (2015) Interactions between microplastics and phytoplankton aggregates: Impact on their respective fates. Mar Chem 175:39-46. https://doi.org/10.1016/j.marchem.2015.04.003

Lu YJ, Jang AL, Dou BR, Wang C, Wang CH (2010) Effect of Cd ( () and Zn ( $)$ ) on growth and biochemical composition of alga Nitzschia closterium (in Chinese). J Dalian Fish Univ 25(2):178-182. https://doi.org/10.3969/j.issn.1000-9957.2010.02.016

Machado DM, Soares EV (2014) Modification of cell volume and proliferative capacity of Pseudokirchneriella subcapitata cells exposed to metal stress. Aquat Toxicol 147:1-6. https://doi.org/10.1016/j.aquatox.2013.11.017

Manusadžianas L, Caillet C, Fachetti L, Gylyte B, Grigutyte R, Jurkoniene S, Karitonas R, Sadauskas K, Thomas F, Vitkus R, Férard JF (2012) Toxicity of copper oxide nanoparticle suspensions to aquatic biota. Environ Toxicol Chem 31(1):108-114. https://doi.org/10.1002/etc.715

Marangoni LFB, Marques JA, Duarte GAS, Pereira CM, Calderon EN, Castro BC, Bianchini A (2017) Copper effects on biomarkers associated with photosynthesis, oxidative status and calcification in the Brazilian coral Mussismilia harttii (Scleractinia, Mussidae). Mar Environ Res 130:248-257. https://doi.org/10.1016/j.marenvres.2017.08.002 
M'Rabet C, Pringault O, Zmerli-Triki H, Gharbia HB, Couet D, Yahia OKD (2018) Impact of two plasticderived chemicals, the Bisphenol $\mathrm{A}$ and the di-2-ethylhexyl phthalate, exposure on the marine toxic dinoflagellate Alexandrium pacificum. Mar Pollut Bull 126:241.

https://doi.org/10.1016/j.marpolbul.2017.10.090

Müller E, Behra R, Sigg L (2016) Toxicity of engineered copper (Cu0) nanoparticles to the green alga Chlamydomonas reinhardtii. Environ Chem 13(3):457-463. https://doi.org/10.1071/EN15132

Nguyen MK, MoonYJ, Lee YC (2020) Microalgal ecotoxicity of nanoparticles: An updated review, Ecotoxicol Environ Saf 201:110781. https://doi.org/10.1016/j.ecoenv.2020.110781

OECD (2011) OECD Guidelines for the testing of chemicals, section 2: Effects on biotic systems. Test No. 201: Freshwater alga and cyanobacteria, growth inhibition test. Organisation for economic co-operation and development, Paris. https://doi.org/10.1787/20745761

Passow U (2002) Transparent exopolymer particles (TEP) in aquatic environments. Prog Oceanogr 55(34):287-333. https://doi.org/10.1016/S0079-6611(02)00138-6

Šepič E, Bricelj M, Leskovšek H (2003) Toxicity of fluoranthene and its biodegradation metabolites to aquatic organisms. Chemosphere 52:1125-1133. https://doi.org/10.1016/S0045-6535(03)00321-7

Shi LY (2007) Nanometer materials. East China University of Science and Technology Press, Shanghai

Staats N, Stal JL, Luuc RM (2000) Exopolysaccharide production by the epipelic diatom Cylindrotheca closterium: effects of nutrient conditions. J Exp Mar Biol Ecol 249(1):13-27.

https://doi.org/10.1016/S0022-0981(00)00166-0

Stampoulis D, Sinha SK, White JC (2009) Assay-Dependent Phytotoxicity of Nanoparticles to Plants. Environ Sci Technol 43:24, 9473-9479. https://doi.org/10.1021/es901695c

Sun Y, Wang H, Lv FH, Yu CY, Liu HM (2016) Toxicity of $\mathrm{TiO}_{2}$ Nanoparticles to Chlorella sp. and Nitzschia Closterium (in Chinese). Mod Agric Sci Technol 1:217-219 \& 223. https://doi.org/10.3969/j.issn.10075739.2016.01.137

Tang YL, Li SY, Lu Y, Li Q, Yu SL (2015) The influence of humic acid on the toxicity of Nano-ZnO and $\mathrm{Zn}^{2+}$ to the Anabaena sp. Environ Toxicol 30(8):895-903. https://doi.org/10.1002/tox.21964

Toh PY, Tai WY, Ahmad AL, Lim JK, Chan DJC (2016) Toxicity of bare and surfaced functionalized iron oxide nanoparticles towards microalgae. Int J Phytoremediation 18:643-

650. https://doi.org/10.1080/15226514.2015.1086300

Turan NB, Erkan HS, Engin GO, Bilgili MS (2019) Nanoparticles in the aquatic environment: Usage, properties, transformation and toxicity-A review. Process Saf Environ Prot 130:238-249. https://doi.org/10.1016/j.psep.2019.08.014 
Underwood GJC, Boulcott M, Raines CA, Waldron K (2004) Environmental effects on exopolymer production by marine benthic diatoms: dynamics, changes in composition, and pathways of production. J Phycol 40(2):293-304. https://doi.org/10.1111/j.1529-8817.2004.03076.x

Unrine JM, Colman BP, Bone AJ, Gondikas AP, Matson CW (2012) Biotic and abiotic interactions in aquatic microcosms determine fate and toxicity of Ag nanoparticles. Part 1. Aggregation and dissolution. Environ Sci Technol 46:6915-6924. https://doi.org/10.1021/es204682q

Wang F, Guan W, Xu L, Ding ZY, Ma H, Ma AZ, Terry N (2019) Effects of Nanoparticles on Algae: Adsorption, Distribution, Ecotoxicity and Fate. Appl Sci 9(8):1534. https://doi.org/10.3390/app9081534

Wang GY, Wang HJ, Li XL (1997) Editor-in-chief of Chinese society of corrosion and protection, corrosion and protection of natural environment: Atmosphere, sea water and soil (in Chinese). Chemical Industry Press, Beijing, pp 87-90.

Wang H, Ebenezerv V, Ki J (2018) Photosynthetic and biochemical responses of the freshwater green algae Closterium ehrenbergii Meneghini (Conjugatophyceae) exposed to the metal coppers and its implication for toxicity testing. J Microbiol 56(6):426-434. https://doi.org/10.1007/s12275-018-8081-8

Wang SS, Lv J, Ma JY, Zhang SZ (2016) Cellular internalization and intracellular biotransformation of silver nanoparticles in Chlamydomonas reinhardtii. Nanotoxicology 10:1129-1135. https://doi.org/10.1080/17435390.2016.1179809

Wong SWY, Leung PTY, Djurišić AB, Leung KMY (2010) Toxicities of nano zinc oxide to five marine organisms: influences of aggregate size and ion solubility. Anal Bioanal Chem 396(2):609-618. https://doi.org/10.1007/s00216-009-3249-z

Wu F, Harper BJ, Crandon LE, Harper SL (2020) Assessment of Cu and CuO nanoparticle ecological responses using laboratory small-scale microcosms. Environ Sci: Nano 7(1):105-115. https://doi.org/10.1039/c9en01026b

Wu HH, Wan P Huang MS (2014) Toxicity regression calculation method and introduction of corresponding software utilization. J Anhui Agric Sci 42(27):9335-9338 \& 9340. https://doi.org/10.3969/j.issn.0517-6611.2014.27.030

Xiang L, Mo CH, Lu XH, Wu XL, Li YW, Huang XP, Qu XL, Hao Y, Huang YY (2011) Toxicity of copper oxide nanoparticles to the seed germination of Chinese cabbage. J Agro-Environ Sc. 9:1830-1835. https://doi.org/10.1016/S1671-2927(11)60313-1

Xue QN, Wang R, Tan LJ, Wang JT (2018) Effects of the extracts from the filtrate of Phaeodact ylum triconutum on Prorocentrum donghaiense and Dunaliella salina analyzed by different physiological parameters (in Chinese). Acta Oceanol Sin 40(4):119-126. https://doi.org/10.3969/j.issn.02534193.2018.04.011 
Ye N, Wang Z, Fang H, Wang S, Zhang F (2017) Combined ecotoxicity of binary zinc oxide and copper oxide nanoparticles to Scenedesmus obliquus. J Environ Sci Heal Part A 52:555-

560. https://doi.org/10.1080/10934529.2017.1284434

Yuan ZH, Tang XL, Bai YQ, Tang T, Yu CP (2013) Effects of silver nanoparticles on photosynthesis and respiration of Chlorella vulgaris (in Chinese). China Environ Sci 8:1468-1473.

https://doi.org/10.3969/j.issn.1000-6923.2013.08.018

Zhai XJ, Zhang N (1999) Research Development of Nanometer Metal Materials (in Chinese). Mater Rep 6:22-24. http://www.cnki.com.cn/Article/CJFDTotal-CLDB199906008.htm

Zhang C, Chen XH, Tan LJ, Wang JT (2018) Combined toxicities of copper nanoparticles with carbon nanotubeson marine microalgae Skeletonema costatum. Environ Sci Pollut Res 25:13127-13133. https://doi.org/10.1007/s11356-018-1580-7

Zhang C, Wang JT, Tan LJ, Chen XH (2016) Toxic effects of Nano-ZnO on marine microalgae Skeletonema costatum: Attention to the accumulation of intracellular Zn. Aquat Toxicol 178:158-164. https://doi.org/10.1016/j.aquatox.2016.07.020

Zhang PY, Chen Y, Yang GP (2015) Composition and distribution of dissolved and particulate amino acids in seawater of East China Sea in autumn. Oceanol Limnol Sin 46(2):329-339. https://doi.org/10.11693/hyhz20140500151

Zhang PY, Yang GP, Chen Y, Leng WS, Ji CX (2016) Temporal and spatial variations of particulate and dissolved amino acids in the East China Sea. Mar Chem 186:133-144.

https://doi.org/10.1016/j.marchem.2016.09.004

Zhao J, Cao, XS, Liu XY, Wang ZY, Xing BS (2016) Interactions of CuO nanoparticles with the algae Chlorella pyrenoidosa: adhesion, uptake, and toxicity. Nanotoxicology 10(9):1-31. https://doi.org/10.1080/17435390.2016.1206149

Zhao J, Cao X, Wang Z, Dai Y, Xing B (2017) Mechanistic understanding toward the toxicity of graphenefamily materials to freshwater algae. Water Res 111:18-27.

https://doi.org/10.1016/J.WATRES.2016.12.037

Zhao JF, Liu SX, Liu N, Zhang H, Zhou QZ, Ge F (2019) Accelerated productions and physicochemical characterizations of different extracellular polymeric substances from Chlorella vulgaris with nano-ZnO. Sci Total Environ 658:582-589. https://doi.org/10.1016/j.scitotenv.2018.12.019

Zhou C, Vitiello V, Pellegrini D, Wu C, Morelli E, Buttino I (2016) Toxicological effects of CdSe/ZnS quantum dots on marine planktonic organisms. Ecotoxicol Environ Saf 123:26-31. https://doi.org/10.1016/J.ECOENV.2015.09.020 
Zhu XL, Zhao WH, Chen XH, Zhao T, Tan LJ, Wang JT (2020) Growth inhibition of the microalgae Skeletonema costatum under copper nanoparticles with microplastic exposure. Mar Environ Res 158:105005. https://doi.org/10.1016/j.marenvres.2020.105005

\section{Figures}

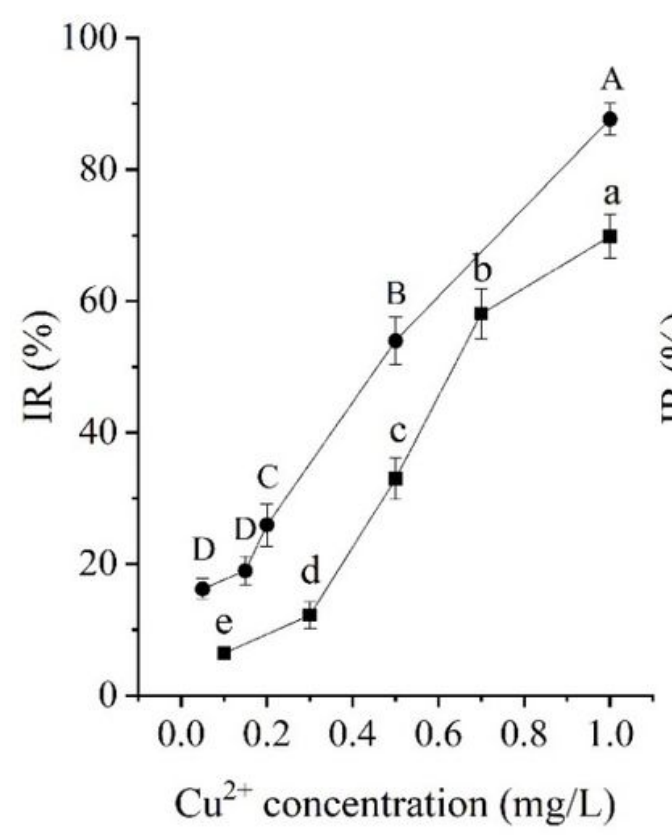

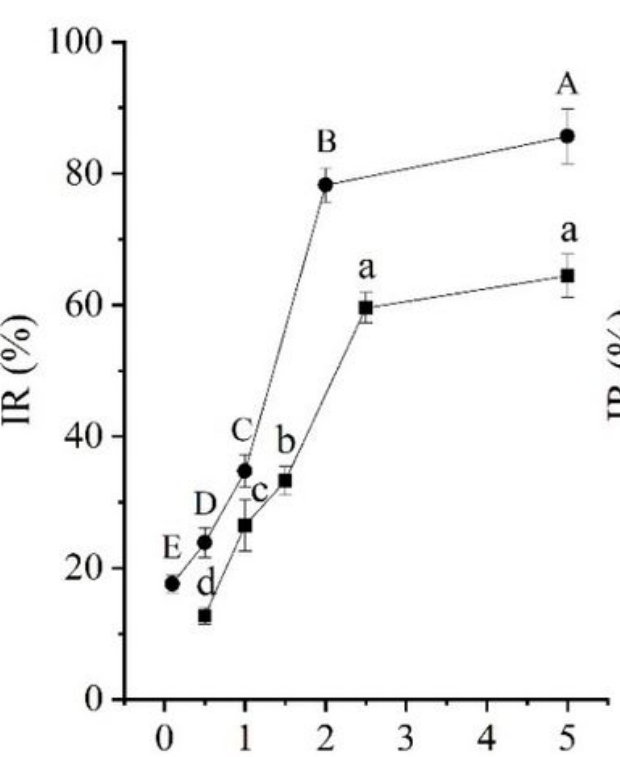

Nano-Cu concentration $(\mathrm{mg} / \mathrm{L})$

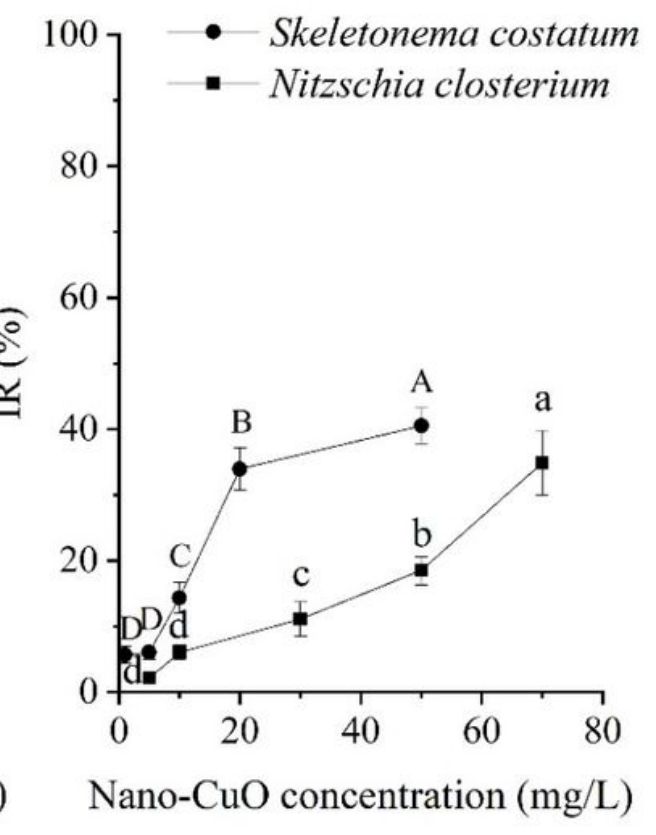

\section{Figure 1}

Inhibition ratios of microalgae after $48 \mathrm{~h}$ exposure. The different letters indicated statistically significant differences $(p<0.05)$ different concentration groups in each copper material treatment. The capital letters were used for $\mathrm{S}$. costatum, and the small letters were used for N. closterium. Error bars: standard deviation. 

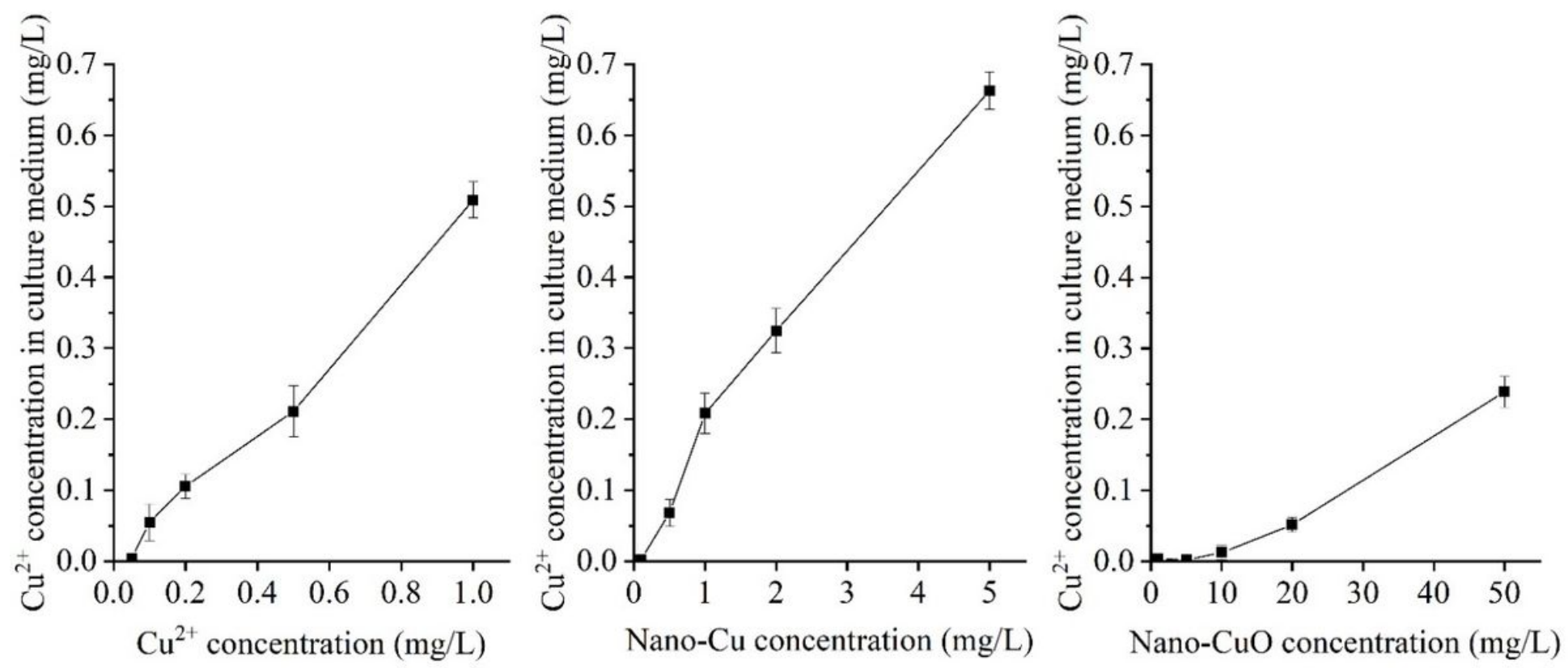

Figure 2

Cu2+ concentration in the culture medium of S. costatum. Error bars: standard deviation.

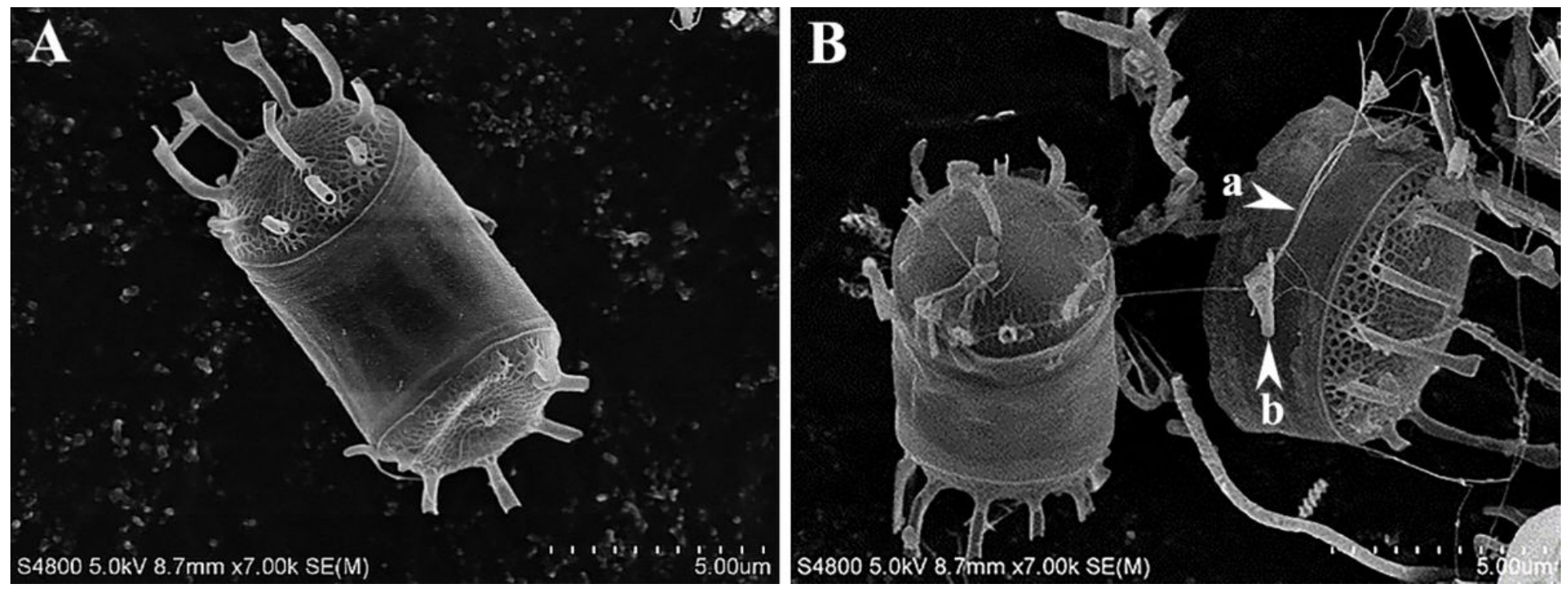

Figure 3

SEM images of S. costatum exposed to nano-Cu (A: Control, B: treatment with nano-Cu). Arrow a: extracellular polymeric substances. Arrow b: broken siliceous thorns. 



\section{Figure 4}

Intracellular amino acids composition and proportion for N. closterium (A) and S. costatum (B) exposed to $\mathrm{Cu} 2+$, nano-Cu and nano-CuO at $48 \mathrm{~h}$. Left $\mathrm{Y}$-axis and bar: intracellular amino acids concentrations. Right $\mathrm{Y}$-axis and line: the proportion of four major amino acids in intracellular amino acids. 

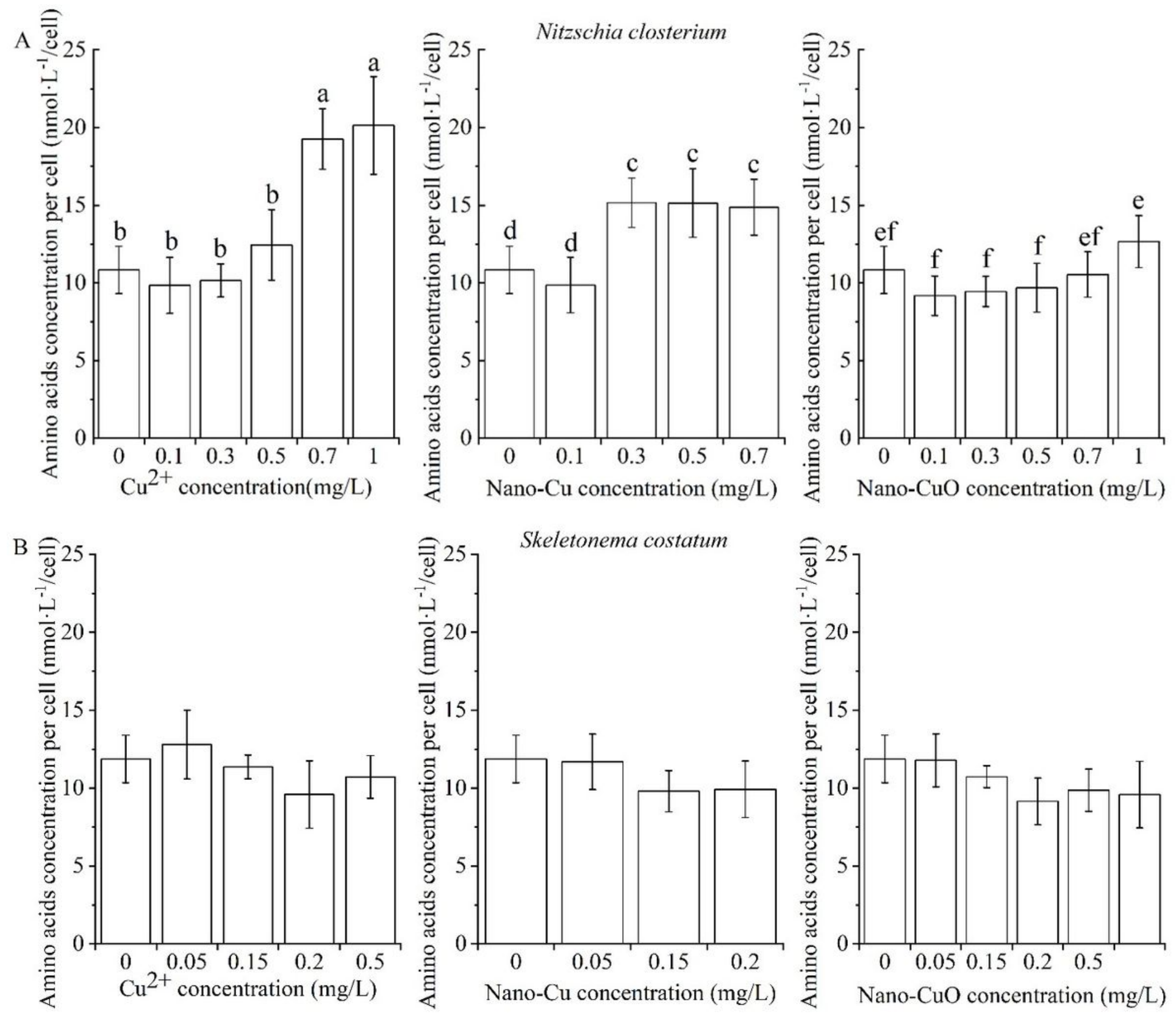

Figure 5

Per-cell intracellular amino acids concentration of N. closterium (A) and S. costatum (B). Different small letters indicated statistically significant differences $(p<0.05)$ among different concentration groups in each copper material treatment. Error bars: standard deviation. 


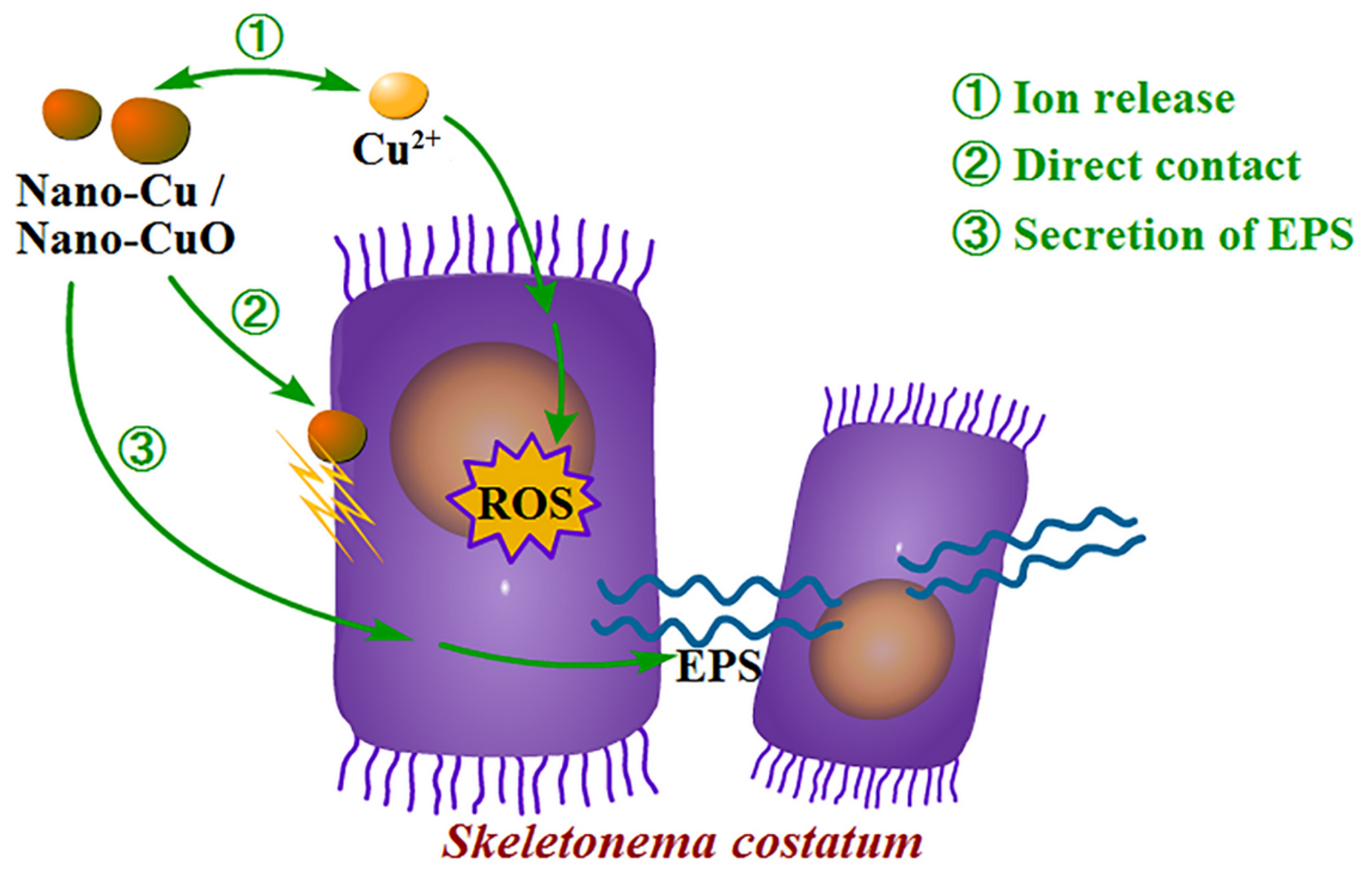

Figure 6

Schematic diagram of the way that nano-Cu and nano-CuO affect algae cells.

\section{Supplementary Files}

This is a list of supplementary files associated with this preprint. Click to download.

- Supplementaryinformation0309.docx 